Newfoundland and Labrador Studies

\title{
Jennifer J. Connor and Katherine Side, eds. The Grenfell Medical Mission and American Support in Newfoundland and Labrador, 1890s-1940s
}

\section{Bonnie White}

Volume 34, Number 2, 2019

URI: https://id.erudit.org/iderudit/1072655ar

DOI: https://doi.org/10.7202/1072655ar

See table of contents

Publisher(s)

Faculty of Arts, Memorial University

ISSN

1719-1726 (print)

1715-1430 (digital)

Explore this journal

\section{Cite this review}

White, B. (2019). Review of [Jennifer J. Connor and Katherine Side, eds. The Grenfell Medical Mission and American Support in Newfoundland and Labrador, 1890s-1940s]. Newfoundland and Labrador Studies, 34(2), 325-329. https://doi.org/10.7202/1072655ar 
BOOK REVIEWS

Jennifer J. Connor and Katherine Side, eds. The Grenfell Medical Mission and American Support in Nerwfoundland and Labrador, 1890s-1940s. Montreal and Kingston: McGill-Queen's University Press, 2019. ISBN 978-0-773-55487-0

The title, The Grenfell Medical Mission and American Support in Newfoundland and Labrador, 1890s-1940s, is somewhat misleading as this book offers not only an examination of American financial support for Wilfred Grenfell and his vision of a medical mission in Newfoundland, but also seeks to examine the scope and success of the International Grenfell Association (IGA) within local and international contexts. The collaboration between Jennifer J. Connor and Katherine Side presents a well-rounded, but not holistic, examination of the social, economic, and ideological factors that shaped the mission from the late nineteenth century to the mid-twentieth century.

While much of the study focuses on the organizational structure of the IGA, with significant attention devoted to its origins and early development, it also integrates local and oral histories that provide balance to the institutional approach adopted for this study. In doing so, it successfully synthesizes historiographical analysis with documentary materials from Canada and the United States, as well as a number of contemporary interviews and first-person testimonials. As an organizational history, it traces the Grenfell medical mission as it transitioned from a Victorian charity to an American-style philanthropic enterprise after the First World War. The authors in this collection have demonstrated the mission's capacity to adapt to the changing socio-political climate in Newfoundland and Labrador between the 
fin-de-siècle and Confederation in 1949 and its ability to overcome what Grenfell saw as political and economic mismanagement in the colony that limited health-care reforms and kept key services from outport communities. The collection covers a variety of topics, but it centres primarily on American financial, structural, and ideological influence that came to dominate the mission.

The Grenfell medical mission began as an amalgam of charity efforts in Britain and American investments in the colony, and while studies of the mission have often highlighted the importance of the British connection, James Hiller in Chapter 1 carefully deconstructs the Anglocentric narrative to emphasize the influences of not just American financial investors, but also the difficulty of working within the paternalistic structures of the colony itself. Hiller exposes the challenges faced by the mission as it confronted the truck system and protectionists that resisted outside interference. The more changes Grenfell tried to initiate, the more outside resources he needed as the mission moved towards a corporate model.

Part I is dedicated to how the mission was shaped by the increase in American influence, including a vast number of volunteers from elite American universities and colleges, and how it moulded imperial identities. In its early years the mission relied on volunteers who were called to service by the apparent Christian character of the venture and on specialists who focused on Victorian conceptions of health that included class-based understandings of the interconnectedness of moral and physical well-being. Jennifer Connor in Chapter 2 and Ronald Numbers in Chapter 3 underscore the intangible elements that reformers believed were central to the mission's work, such as the benefits students and volunteers would gain as they worked on the individual attributes Grenfell believed were necessary for a successful life: teamwork, leadership skills, and a strong work ethic. In Chapter 4 Heidi Coombs-Thorne extends the prevailing focus on the need to build good character with her discussion of Charles F. Karnopp, whose mismanagement of the mission's accounts "threatened to discredit the entire Grenfell mission and destroy the public favour that Grenfell 
had been building for years" (p. 98). Coombs-Thorne's careful handling of how responsibility was prescribed, as seen in the precarity faced by the mission on account of Karnopp's arrest and conviction, strengthens the central argument in Part I that the gradual Americanization of the mission was necessary in order to accelerate much needed change.

While the internationalization of the Grenfell mission in Newfoundland was necessary to advance Grenfell's vision, this process was not so complete as to subvert local actors and influences. Sporting activities and clothing drives, two areas of the mission's work that have not received enough scholarly attention, show that the communities serviced by the mission underwent extensive change, but also shaped the mission's activities and outreach programs. Taken as a whole, Part II challenges traditional approaches that use binary categories urban/rural, core/peripheral, modern/traditional - to understand the relationships between the various parts of the colony. While modern sports were largely absent on the island, for example, John Matchim in Chapter 5 sets out to illustrate how sport in northern Newfoundland was shaped by international sporting preferences but also was infused with the particularities of local tastes and customs. This chapter is more preliminary than conclusive, but when read in conjunction with Emma Lang and Katherine Side's study (Chapter 6) of the relationship between clothing and respectability, it demonstrates the connectivity of local and international processes that shaped the character of the IGA. These chapters confirm that the IGA did not subvert local traditions in favour of an international corporatist model, but as Lang and Side show, Grenfell deviated from his preference for a cash economy with the creation of a clothing exchange system that was consistent with Newfoundlanders' preference for self-sufficiency and resourcefulness.

What emerged from Grenfell's careful oversight was an efficient system that helped to meet the needs, broadly defined, of northern communities. While sport, clothing exchanges, and even the construction of physical structures demonstrate the cultural exchange that was very much central to the mission's sustainability, Helen Woodrow 
(Chapter 8) and J.T.H. Connor (Chapter 10) provide two of the most valuable chapters in the collection with their work, respectively, on education and health care. These chapters explore the success of the mission in modernizing and expanding education and health services in the north. In both cases, sparse populations outside major centres prevented the allocation of scarce resources to those areas. The IGA attracted well-educated teachers, who were tasked with a miscellany of responsibilities, and well-credentialed medical teams that revolutionized medical services for those most disaffected by the lack of a centralized health-care system in Newfoundland prior to 1949.

Woodrow and Connor are ambitious in their tasks, and the wealth of information and the critical importance of both education and health care to the mission's success warrants further study. Grenfell was particularly critical of the Newfoundland education system, which he believed was beset by inefficiencies, but Woodrow resists a transplantive approach wherein the infusion of external professionals was the colony's only hope for progress. Rather, she continues the book's central argument of integrating local and international influences by arguing that reparative methods were used to help locals help themselves and future generations. Through the concepts of social uplift and self-fulfillment, mission staff used an expansive understanding of education and mental health that positioned northern communities at a crossroads between tradition and modernity.

The introduction of a private medical mission in pre-Confederation Newfoundland was a complicated undertaking and perhaps most effectively showcases the complex connections between local, regional, and international influences. The hospitals at St. Anthony and Twillingate illustrate the IGA's growing capacity to advance its mandate through external aid, but also the extent to which the hospitals facilitated further economic development, including the establishment of an American military base on the island.

This is a capacious work and the Editors' Conclusion, rather than simply summarizing the key arguments put forward by the book's contributors, clearly outlines avenues of investigation not covered in 
the collection. The conclusion is certainly helpful in this regard, but this space might have been better devoted to tying together the various topics covered in the book. Part I devotes considerable attention to the formation of the mission, an area the editors noted was essential to fully understanding the scope and nature of the IGA, and while the level of detail is appreciated, the chapters can be repetitive in core areas. Part II covers such an array of topics that it suffers from some organizational challenges. Some sections transition nicely from one topic to another, while others seem tangentially linked but without obvious connections. Nevertheless, Connors and Side have given us an essential work on the Grenfell mission in Newfoundland, and taken as a whole the collection convincingly demonstrates that while the mission became an American operation, it was not simply the product of one man's vision, nor did it ignore the local structures, customs, and experiences of the people the mission served.

Bonnie White Grenfell Campus, Memorial University of Newfoundland 